
\title{
Kajian Deskriptif Kurikulum Islam Menurut Ali
Ahmad Madkur
}

\author{
Yuli Supriani ${ }^{1}$, Kardi Leo ${ }^{2}$, Izzuddin Musthafa ${ }^{3}$ \\ 1,2,3Universitas Islam Negeri Sunan Gunung Djati Bandung, Indonesia \\ E-mail: yulisupriani30@gmail.com, kardileo84@gmail.com, izzuddin@uinsgd.ac.id
}

\begin{tabular}{l}
\hline Article Info \\
\hline Article History \\
Received: 2021-10-09 \\
Revised: 2021-11-02 \\
Published: 2021-11-28
\end{tabular}

Keywords:

Curriculum

Islam;
Ali Ahmad Madkur

\begin{abstract}
This research is a study of the Islamic curriculum according to Ali Ahmad Madkur. The type of research used is qualitative with library research method. The results of the study show that: 1) In fact the integration of human experience in the Islamic education curriculum is relevant to natural Islamic thought (al-kaun), 2) In fact, the heavenly rules should create a unity of principles, namely; entirely from the one God and invites / calls to the principles of aqidah, 3) The origin of creation is one, and creation is the source of the direct will of God Almighty, 4) The origin of all religions is one, namely worshiping Allah and do not associate partners with Him, 5) The origin of the Prophets is one, and they are one people and have the same goal, 6) The origin of nature is integrated, the origin of the humanities is also integrated, 7) The formation of humans who are capable of positively and actively (interactively) in building or cultivating the earth (natural resources) in accordance with the methods (guidelines, rules) of Allah SWT, 8) There are three kinds of integration, namely; horizontal, vertical and external integration, 9) In fact, the ultimate goal of integration is learning communication to achieve plenary results (darajat-u al-kamal) which have been prepared (facilitated) by Allah SWT, 10) Indeed, the curriculum material allows it to be divided into six complementary areas, including; poetry and law, humanities, exact sciences, biological sciences, expressive arts and sports education.
\end{abstract}

\begin{tabular}{l}
\hline Artikel Info \\
\hline Sejarah Artikel \\
Diterima: 2021-10-09 \\
Direvisi: 2021-11-02 \\
Dipublikasi: 2021-11-28
\end{tabular}

Kata kunci:

Kurikulum

Islam;

Ali Ahmad Madkur.

\section{PENDAHULUAN}

Kurikulum sebagai buku pedoman (guidance book) primer proses belajar mengajar baik dalam ruang lingkup nasional sekolah formal khususnya, nonformal, dan informal umumnya berada pada posisi sentral dalam mengembangkan kemampuan peserta didik yang berupa aspek kognitif, afektif dan pikomotorik peserta didik secara simultan, aspek-aspek tersebut merupa-

\begin{abstract}
Penelitian ini merupakan kajian tentang kurikulum islam menurut Ali Ahmad Madkur. Jenis penelitian yang digunakan adalah kualitatif dengan metode library research. Hasil penelitian menunjukan bahwa: 1) Sesungguhnya integrasi pengalaman manusia didalam kurikulum pendidikan Islam relevan dengan pemikiran Islam alam (al-kaun), 2) Sesungguhnya aturan-aturan langit seharusnya menciptakan kesatuan prinsip, yaitu; seluruhnya dari Allah yang satu dan mengajak/menyeru kepada prinsipprinsip aqidah, 3) Asal penciptaan itu adalah satu, dan penciptaan itu merupakan sumber kehendak langsung dari Allah Yang Maha Esa, 4) Asal agama-agama itu adalah satu, yaitu beribadah kepada Allah dan tidak menyekutukan-Nya, 5) Para Nabi asalnya adalah satu, dan mereka merupakan umat yang satu serta memiliki tujuan yang satu pula, 6) Asal alam itu adalah terintegrasi, asal humaniora yang satu itu aktif (interaktif) didalam membangun atau mengolah bumi (sumber Daya Alam) sesuai dengan metode (pedoman, aturan) Allah SWT, 8) Integrasi itu ada tiga macam, yaitu; integrasi horizontal, vertical dan eksternal, 9) Sesungguhnya integrasi itu tujuan akhirnya adalah komunikasi belajar untuk mencapai hasil paripurna (darajat-u alkamal) yang telah disiapkan (difasilitasi) oleh Allah SWT, 10) Sesungguhnya materi kurikulum itu, memungkinkan untuk dibagi menjadi enam bidang yang saling melengkapi, diantaranya; ilmu-ilmu puisi dan hukum, ilmu-ilmu humaniora, ilmuilmu eksakta, ilmu-ilmu biologi, ilmu-ilmu seni ekspresif dan pendidikan olah raga.
\end{abstract} yang mempengaruhi perkembangan kurikulum pada umumnya adalah tujuan yang hendak dicapai, tuntutan masyarakat global, isi atau materi yang disesuaikan dengan perkembangan ilmu pengetahuan dan teknologi, serta kondisi psikologis peserta didik. Disamping itu, faktor yang terpenting lagi mempengaruhi perkemba- 
ngan kurikulum kaitannya dengan Pendidikan Islam adalah faktor sumber hukum Islam berupa al-Quran-Hadits.

Integrasi pengalaman manusia didalam kurikulum pendidikan Islam sesuai dengan pemikiran Islam tentang keberadaan, alam (alkaun), penciptaan (al-wujud) dan manusia (alinsan). Sebagaimana juga bahwa integrasi kurikulum pendidikan Islam sesuai dengan pandangan Islam terhadap kesatuan penciptaan (wahdat-u al-wujud) dan pengintegrasian seluruh komponennya, adalah langsung bersumber dari kesatuan yang mutlak yaitu Allah SWT. Sesungguhnya Al-Qur`an telah menjelaskan bahwa syariat-syariat yang bersumber dari langit (alSyara'i al-samawiyyah) semuanya adalah memiliki prinsip yang satu: yaitu semuanya bersumber dari Tuhan Yang Satu, mengajak kepada dasar-dasar keyakinan ('aqidahasasiyah).

Menurut Sudjana dalam (Hasbi, 2021) bahwa kurikulum berasal dari Yunani kuno yaitu Curriculum dari kata Curir yang artinya pelari dan Curere yang artinya tempat berpacu. Curriculum di artikan jarak yang harus di tempuh oleh pelari. Dari makna yang terkandung berdasarkan rumusan masalah tersebut kurikulum dalam pendidikan di artikan sebagai sejumlah mata pelajaran yang harus ditempuh atau disekesaikan anak didik untuk memperoleh ijasah. As-Syaibany dalam bukunya Falsafah Pendidikan Islam kurikulum sama dengan manhaj dalam bahasa arab yang bermakna jalan yang terang, atau jalan yang dilalui oleh manusia pada berbagai bidang kehidupannya. Manhaj yang dimaksud adalah jalan terang yang dilalui oleh pendidik dengan peserta didik untuk mengembangkan pengetahuan, ketrampilan dan sikap mereka (Al-Syaibani, 1979).

Galen Saylor dan William M. Alexander dalam dalam (Mayasari, 2021) menjelaskan arti kurikulum sebagai berikut "The curriculum is the sum totals of schools efforts to influence learning, whether in the class room, on the play ground, or out of school. Segala usaha sekolah untuk mempengaruhi anak belajar, apakah dalam ruang kelas, di halaman sekolah, atau di luar sekolah termasuk kurikulum. Kurikulum meliputi juga apa yang disebut kegiatan ekstra kulikuler (Tanjung, 2021).

Undang-undang RI No 20 Tahun 2003 tentang Sistem Pendidikan Nasional Pasal 1 ayat 19 mengatakan bahwa Kurikulum adalah seperangkat rencana dan pengaturan mengenai tujuan, isi, tambahan pelajaran serta cara yang digunakan sebagai pedoman penyelenggaraan kegiatan pembelajaran untuk mencapai tujuan pendidikan tertentu. Menurut (Arifudin, 2021) bahwa dalam pengertian kontemporer "kurikulum" diartikan lebih luas, karena kurikulum tidak lagi menekankan pada daftar isi materi rencana pelajaran yang memiliki topik-topik yang telah disusun, tapi lebih menekankan kepada pengalaman-pengalaman proses belajar mengajar yang dapat diberikan kepada para murid dalam konteks dimana murid-murid berada.

Dalam proses pendidikan, kurikulum merupakan alat untuk mencapai tujuan pendidikan. Tanpa kurikulum yang sesuai dan tepat akan sulit untuk mencapai tujuan dan sasaran pendidikan yang diinginkan. Menurut (Nadeak, 2020) bahwa konsep kurikulum diatas, dapat diklasifikasikan ke dalam empat jenis pengertian yang meliputi: (1) kurikulum sebagai produk; (2) kurikulum sebagai program; (3) kurikulum sebagai hasil yang diinginkan: dan (4) kurikulum sebagai pengalaman belajar bagi peserta didik. Hal senada juga dikemukakan oleh Hamid Hasan dalam (Juhji, 2020) bahwa konsep kurikulum dapat ditinjau dalam empat dimensi, yaitu: pertama, kurikulum sebagai suatu ide; yang dihasilkan melalui teori-teori dan penelitian, khususnya dalam bidang kurikulum dan pendidikan. Kedua, kurikulum sebagai suatu rencana tertulis, sebagai perwujudan dari kurikulum sebagai suatu ide; yang didalamnya memuat tentang tujuan, bahan, kegiatan, alatalat, dan waktu. Ketiga, kurikulum sebagai suatu kegiatan, yang merupakan pelaksanaan dari kurikulum sebagai suatu rencana tertulis; dalam bentuk praktek pembelajaran. Keempat, kurikulum sebagai suatu hasil yang merupakan konsekwensi dari kurikulum sebagai suatu kegiatan, dalam bentuk ketercapaian tujuan kurikulum yakni tercapainya perubahan perilaku atau kemampuan tertentu dari para peserta didik.

Isi kurikulum harus disusun sedemikian rupa sehingga tidak menyimpang dari tujuan kurikulum. Isi kurikulum merupakan komponen yang berhubungan dengan pengalaman belajar yang harus dimiliki oleh peserta didik dan juga berkaitan dengan semua aspek yang berkaitan dengan isi materi pelajaran secara keseluruhan diarahkan untuk mencapai tujuan yang telah ditentukan. Ronald C. Doll dalam (Tanjung, 2020) mengemukakan, ada beberapa kriteria dalam menentukan isi kurikulum yaitu: 1) Validitas dan signifikansi bahan (subject matter) 
sebagai disiplin ilmu, 2) Keseimbangan ruang lingkup bahan (scope) dan kedalamannya (depth), 3) Kesesuaian dengan kebutuhan dan minat peserta didik, 4) Daya tahan (durability) bahan, 5) Hubungan logis bahan antara ide poko (main ideas) dan konsep dasar (basic concept), 6) Kemampuan peserta didik mempelajari bahan tersebut, 7) Kemungkinan menjelaskan bahan itu dengan data dari disiplin ilmu lain.

Tentang isi kurikulum pendidikan Islam, secara garis besar (Al-Syaibani, 1979) mengatakan bahwa isi kurikulum pendidikan Islam mempunyai corak tersendiri, ia membagi isi kurikulum pendidikan Islam itu kedalam lima kelompok. Pertama, semua yang diajarkan bercorak agama bersumber dari al-Qur'an dan Sunnah. Kedua, Isi kurikulum harus mencakup semua aspek, baik dari segi intelektual, psikologis, social dan spiritual dengan semangat mengembangkan pemikiran dan penghalusan akhlak peserta didik. Ketiga, isi kurikulum memiliki keseimbangan antara ilmu-ilmu dunia dengan ilmu agama (akhirat). Keempat, Kurikulum pendidikan Islam berisikan tentang ketrampilan-ketrampilan fisik dan kejuruan. Kelima, isi kurikulum pendidikan Islam juga memperhatikan bakat dan minat peserta didik

Menurut (Al-Abrasy, 1985) lebih merinci lagi isi kurikulum Pendidikan Islam menjadi beberapa macam yang meliputi: 1) Materi yang disusun tidak menyalahi fitrhamanusia, 2) Adanya relevansi dengan tujuan pendidikan Islam, yaitu beribadah kepada Allah SWT, 3) Di sesuaikan dengan perkembangan peserta didik, 4) Mengarahkan peserta didik kepada obyek empiric, sehingga peserta didik memiliki ketrampilan untuk memenuhi kebutuhan hidup, 5) Adanya keserasian antara materi satu dengan lainnya dalam penyusunan kurikulum secara integral dan terorganisasi, 6) Kurikulum yang disusun memiliki relevansinya dengan hal-hal yang mutakhir dan sesuai dengan tujuan falsafah Negaranya, 7) Kurikulum memiliki setrategi dan metode yang relevan dengan materi ajar dan peserta didik, 8) Materi pelajaran bersifat teoritis dan praktis, 9) Materi pelajaran yang disusun sesuai dengan perkembangan peserta didik, 10) Isi kurikulum sesuai denhgan aspek-aspek social, 11) Materi pelajaran yang disusun memiliki fungsi pragmatis dan memiliki pengaruh terhadap bidang tertentu, 12) Isi kurikulum tidak memaksa tetapi member peluang fitrah peserta didik untuk refresing dan adanya nilai seni, 13) Isi kurikulum juga memperhatikan pendidikan kejuruan, teknik, industri sebagai lapangan pekerjaan, 14) Isi kurikulum juga mencakup ilmu-ilmu alat untuk mempelajari ilmu yang lain.

Setelah menterjemahkan dan mengkaji teks pendidikan Ali Ahmad Madkur diatas, maka dapat di peroleh sepuluh pokok pikiran Ahmad Ali Madkur, yaitu: 1) Sesungguhnya integrasi pengalaman manusia didalam kurikulum pendidikan Islam relevan dengan pemikiran Islam alam (al-kaun), penciptaan dan manusia, 2) Sesungguhnya aturan-aturan langit seharusnya menciptakan kesatuan prinsip, yaitu; seluruhnya dari Allah yang satu dan mengajak/ menyeru kepada prinsip-prinsip aqidah yakni beriman kepada Allah yang satu (Yang Maha Esa), 3) Asal penciptaan itu adalah satu, dan penciptaan itu merupakan sumber kehendak langsung dari Allah Yang Maha Esa, 4) Asal agama-agama itu adalah satu, yaitu beribadah kepada Allah dan tidak menyekutukan-Nya, 5) Para Nabi asalnya adalah satu, dan mereka merupakan umat yang satu serta memiliki tujuan yang satu pula, 6) Asal alam itu adalah terintegrasi, asal humaniora yang satu itu juga adalah terintegrasi, 7) Sesungguhnya tujuan pengetahuan dan belajar dalam kurikulum pendidikan Islam adalah pembentukan manusia yang mampu secara positif dan aktif (interaktif) didalam membangun atau mengolah bumi (sumber Daya Alam) sesuai dengan metode (pedoman, aturan) Allah SWT, 8) Integrasi itu ada tiga macam, yaitu; integrasi horizontal, vertical dan eksternal, 9) Sesungguhnya integrasi itu tujuan akhirnya adalah komunikasi belajar untuk mencapai hasil paripurna (darajat-u alkamal) yang telah disiapkan (difasilitasi) oleh Allah SWT, 10) Sesungguhnya materi kurikulum itu, memungkinkan untuk dibagi menjadi enam bidang yang saling melengkapi, diantaranya; ilmu-ilmu puisi dan hukum, ilmu-ilmu humaniora, ilmu-ilmu eksakta, ilmu-ilmu biologi, ilmu-ilmu seni ekspresif dan pendidikan olah raga.

Menimbang perlunya rumusan konsep yang jelas tentang gagasan ini, maka penulis bermaksud meneliti lebih jauh mengenai Kurikulum Islam Menurut Ali Ahmad Madkur. Tujuan dari penelitian ini adalah untuk mengetahui secara komprehensif Kurikulum Islam Menurut Ali Ahmad Madkur.

\section{METODE PENELITIAN}

Sesuai dengan karakteristik masalah yang diangkat dalam makalah ini maka penulis 
menggunakan Metode Riset kualitatif, yaitu menekankan analisanya pada data deskriptif berupa kata-kata tertulis yang diamati. Pendekatan kualitatif penulis gunakan untuk menganalisis Kurikulum Islam Menurut Ali Ahmad Madkur, maka dengan sendirinya penganalisaan data ini lebih difokuskan pada Penelitian Kepustakaan (Library Research), yakni dengan membaca, menelaah dan mengkaji bukubuku dan sumber tulisan yang erat kaitannya dengan masalah yang dibahas. Metode yang digunakan dalam kajian ini menggunakan metode atau pendekatan kepustakaan (library research), menurut Zed dalam (Sofyan, 2020) bahwa studi pustaka atau kepustakaan dapat diartikan sebagai serangkaian kegiatan yang berkenaan dengan metode pengumpulan data pustaka, membaca dan mencatat serta mengolah bahan penelitian.

Jenis penelitian ini adalah penelitian kualitatif. Menurut Ibnu dalam (Tanjung, 2019) penelitian kualitatif adalah suatu penelitian yang datanya dinyatakan dalam bentuk verbal dan dianalisis tanpa menggunakan teknik statistik. Berdasarkan beberapa definisi penelitian kualitatif di atas, dapat disimpulkan bahwa penelitian kualitatif adalah suatu penelitian yang datanya dinyatakan dalam bentuk verbal, tidakmenggunakan angka dan analisisnya tanpa menggunakan teknik statistik.

A. Objek Penelitian

Dalam penelitian ini objek penelitian, yaitu objek formal dan objek material. Objek formal dalam penelitian ini berupa data yaitu data yang berhubungan dengan Kurikulum Islam. Sedangkan objek materialnya berupa sumber data, dalam hal ini adalah Kurikulum Islam Ali Ahmad Madkur.

B. Waktu Penelitian

Penelitian ini dilaksanakan pada bulan Agustus sampai dengan Oktober tahun 2021.

C. Teknik Pengumpulan Data

Pengumpulan data yang dilakukan dengan menggunakan teknik dokumentasi yaitu mengadakan survey bahan kepustakaan untuk mengumpulkan bahan-bahan, dan studi literatur yakni mempelajari bahan-bahan yang berkaitan dengan objek penelitian. Teknik pengumpulan data menurut (Bahri, 2021) mengemukakan bahwa merupakan langkah yang paling strategis dalam penelitian karena tujuan untama dari penelitian adalah mendapatkan data. Terdapat beberapa cara atau teknik dalam mengumpulkan data, diantaranya adalah observasi dan dokumentasi, sumber data yang digunakan dalam penelitian ini mencakup data primer dan sekunder. Data primer adalah data yang dikumpulkan langsung dari individu-individu yang diselidiki atau data tangan pertama. Sedangkan data sekunder adalah data yang ada dalam pustaka-pustaka. Data primer dalam penelitian ini adalah buku Kurikulum Islam Menurut Ali Ahmad Madkur, dan data sekunder didapatkan dari jurnal-jurnal baik nasional maupun internasional.

D. Alat Pengumpulan Data

Dalam penelitian ini, penulis akan menggunakan metode dokumentasi sebagai alat untuk pengumpul data karena penelitian ini adalah penelitian kepustakaan. Dengan kata lain, teknik ini digunakan untuk menghimpun datadata dari sumber primer maupun sekunder.

\section{E. Teknik Analisis Data}

Analisis data tidak saja dilakukan setelah data terkumpul, tetapi sejak tahap pengumpulan data proses analisis telah dilakukan. Penulis menggunakan strategi analisis "kualitatif", strategi ini dimaksudkan bahwa analisis bertolak dari data-data dan bermuara pada kesimpulan-kesimpulan umum. Berdasarkan pada strategi analisis data ini, dalam rangka membentuk kesimpulan-kesimpulan umum analisis dapat dilakukan menggunakan kerangka pikir "induktif". Menurut (Sugiyono, 2015) bahwa metode pembahasan menggunakan metode deskriptif-analisis, yaitu menjelaskan serta mengelaborasi ide-ide utama yang berkenaan dengan topik yang dibahas. Kemudian menyajikannya secara kritis melalui sumber-sumber pustaka primer maupun skunder yang berkaitan dengan tema.

\section{F. Prosedur Penelitian}

Data pada penelitian ini dicatat, dipilih dan kemudian diklasifikasikan sesuai dengan kategori yang ada. Pendekatan yang digunakan adalah pendekatan deskriptif analitis. Menurut (Rahayu, 2020) bahwa deskriptif analitis (descriptive of analyze research), yaitu pencarian berupa fakta, hasil dari ide pemikiran seseorang melalui cara mencari, menganalisis, membuat interpretasi serta melakukan generalisasi terhadap hasil penelitian yang dilakukan. Prosedur penelitian ini adalah untuk menghasilkan data deskriptif yang berupa data tertulis setelah melakukan analisis pemikiran (content analyze) dari suatu teks. Setelah penulis 
mengumpulkan bahan-bahan yang berhubungan dengan masalah yang akan di bahas dalam penelitian ini, kemudian penulis menganalisis dan menarasikan untuk diambil kesimpulan.

\section{HASIL DAN PEMBAHASAN}

\section{A. Hasil Riwayat Singkat Hidup Ali Ahmad Madkur}

Salah satu tokoh pendidikan Islam kontemporer di Timur Tengah adalah Ali Ahmad Madkur. Ia dilahirkan di kota Mesir (Qahirah). Gelar sarjana bidang. Pendidikan beliau peroleh di Al-Azhar University Mesir. Sekarang menjadi guru besar (Profesor) di bidang pengembangan kurikulum. Sebelumnya pada tahun 2001 ia dipercaya sebagai Dekan Fakultas Tarbiyah di Universitas Sultan Qobus Oman. Sebagai seorang profesor di bidang kurikulum dan pendidikan Ahmad Madkur dikenal aktif memberikan materi seminar ilmiah di dalam dan di luar negeri yang berkenaan dengan kependidikan dan bahasa di beberapa perguruan tinggi di timur tengah.

Selain aktif dalam berbagai seminar Internasional, ia juga aktif menulis dalam bidang pendidikan maupun bahasa Arab. Diantara karya-karya Ali Ahmad Madkur adalah: Tadris Funun al-Lughah al-Arabiyah. (Dar al-Furqan, Kairo, 2002). Al Ta'lim al-'Aliy Fi al-Wathan al-'Arabi. Al-Manhaj al-Madrasi al-Mu'ashir. (Dar Al Furqan, Kairo, 2009) Manhaj al-Tarbiyah fi al-Tashawwur al-Islami, (Dar al-Fikri al Arabi. Kairo, 2002) Manahij alTarbiyah: Asasuha wa Tathbiqatuha, (Dar alFikr al Arabi, 2001). Thuruq Tadris al-Lughah al-Arabiyyah. Nadhariyyat al-Manahij al Ammah. (Dar al-Furqan, Kairo, 1991).

\section{B. Kandungan Teks}

1) Karakteristik Kelima : Inklusi Inklusi merupakan ciri kelima kurikulum Islam umum, demikian juga dengan kurikulum pendidikan, ciri yang berasal dari ciri pertama kurikulum ini, yaitu dibuat oleh Allah dan bukan oleh manusia. Kekomprehensifan adalah sifat keahlian ilahi. Ada tiga bentuk Inklusi yang pertama dari bentuk-bentuk ini dan yang terbesar adalah kembalinya semua keberadaan. Asal-usulnya, pergerakannya setelah lahir, setiap kemunculan di dalamnya, setiap transformasi, setiap perubahan, dan setiap perkembangan, dan penguasaan, pengelolaan, pembuangan, dan koordinasinya. Allah yang menciptakan alam semesta ini dari awal, dan Dialah yang membawa di dalamnya, dengan kehendak-Nya, setiap perubahan baru dan setiap kemunculan baru . Ini adalah realitas agung tauhid, yang merupakan komponen pertama dari konsep Islam. Jadi, inklusi di sini mewakili kembalinya segala sesuatu di alam semesta ini kepada Tuhan, dan kelengkapan kehendak, pengelolaan, dominasi, dan otoritas-Nya atas segala sesuatu.

Bentuk inklusi yang kedua adalah bahwa kurikulum Islami yang berkaitan dengan semua fakta universal, realitas ketuhanan, realitas alam semesta, realitas kehidupan, realitas perbudakan, dan realitas kemanusiaan, hal tersebut menghubungkan jumlah fakta-fakta itu, dari semua aspeknya, dalam satu konsepsi logis dan bawaan yang komprehensif, berurusan dengan intuisi dan pemikiran manusia dan hati nurani, dan dengan totalitas manusia dalam satu kesatuan yang utuh.

Dengan demikian, ia terdiri dari seperangkat fakta yang dibahas dalam konsepsi ini dalam kelengkapan, keluasan, akurasi dan detailnya, gambaran lengkap yang lengkap dan interpretasi yang komprehensif dan terperinci, yang tidak memerlukan tambahan dari sumber lain, Karena lebih luas dan lebih komprehensif, lebih akurat dan lebih dalam, dan lebih konsisten dan terintegrasi dari setiap sumber lainnya.

Bentuk inklusi yang ketiga adalah bahwa pendekatan Islami menyikapi manusia dengan segala aspeknya, segala kerinduannya, segala kebutuhannya dan segala arahnya. Dia mengembalikannya ke satu sisi yang berurusan dengannya, dan mengarahkannya dengan segala yang diharapkan dan ditakutinya, sama seperti mengembalikannya ke satu sumber dari mana ia menerima konsepsi, konsep, nilai, keseimbangan, hukum, dan hukumnya; Ini karena entitas itu, atau sumber itu, adalah pencipta segalanya, pemilik segalanya, dan dalang semuanya.

Dengan demikian, manusia, dalam segala pikiran, perasaan, dan perilakunya, berbalik ke satu arah apapun cara dan cara yang berbeda. Manusia jika dikumpulkan dengan cara ini menjadi dalam kondisi terbaiknya, karena ia berada dalam 
keadaan "kesatuan, yang merupakan sifat kebenaran dalam segala bidangnya menurut Muhammad Qutb adalah : a) Kesatuan adalah realitas Sang Pencipta, b) Kesatuan adalah realitas alam semesta ini, pada keragaman penampakan, bentuk dan kondisi, c) Kesatuan adalah realitas kehidupan, dalam keragaman ras dan spesies, d) Kesatuan adalah realitas manusia, berdasarkan keragaman individu dan persiapan, serta e) Kesatuan adalah tujuan keberadaan manusia dan itu adalah ibadah pada keragaman bidang ibadah dan bentuknya, dan di mana pun seseorang mencari kebenaran dalam keberadaan ini (dia pasti mencapai kesatuan).

Inklusi dan Konsep Ibadah Dalam Islam merupakan salah satu ciri Islam yang paling menonjol adalah bahwa itu adalah metode ibadah, tetapi ibadah dalam pendekatan ini tidak terbatas pada ritual ibadah yang terkenal seperti sholat, puasa, zakat dan haji dan lain-lain, namun konsep ibadah dalam Islam lebih mendalam dari ini. Ibadah adalah pengabdian kepada Allah semata dan menerima dari Allah saja dalam urusan dunia dan akhirat. Maka itu adalah hubungan permanen dengan Allah dalam segala hal.

Ibadah dalam Islam mencakup seluruh kehidupan manusia, dan itu diwakili dalam dua hal utama, yaitu : Yang pertama adalah pengakuan akan adanya Tuhan Yang Maha Esa yang patut dipuji atas segala sesuatunya, dan yang kedua adalah penerapan hukum-hukum ketuhanan yang dengannya alam semesta berjalan. Allah menjadikan manusia penggantinya di bumi ini. Orang beriman diharuskan untuk mengambil sarana yang membantunya membangun tanah dan memanfaatkan kekayaan dan energi yang telah Allah tempatkan di dalamnya.

Ibadah dalam pengertian ini mencakup seluruh kehidupan. Tidak terbatas pada momen-momen singkat yang diisi oleh ritual-ritual ibadah. Ritual ibadah tidak lain adalah kunci untuk beribadah, atau "stasiun". di mana orang-orang yang berjalan di jalan berdiri untuk mendapatkan persediaan. Islam memperluas konsep ibadah untuk mencakup semua kehidupan. Setiap tindakan yang diarahkan seseorang kepada Tuhan adalah ibadah. Dan setiap amalan yang ditinggalkan seseorang untuk mendekatkan diri kepada Allah dan mencari pahala adalah ibadah. Setiap perasaan yang bersih dalam jiwa adalah ibadah. Dan setiap menahan diri dari perasaan ke bawah demi keridhaan Allah adalah ibadah. Setiap mengingat Allah siang dan malam adalah ibadah, dan kemudian ibadah termasuk kehidupan. Dan manusia menjadi penyembah Tuhan dimanapun dia berpaling kepada Tuhan.

Ibadah dalam Islam bukan sekedar penetapan ritual, tetapi ibadah adalah kehidupan. Semua kehidupan tunduk pada hukum Allah. Dan manusia dalam hidup adalah seorang penyembah selama ia diarahkan dengan segala aktivitasnya kepada Tuhan, terlepas dari jenis pekerjaan atau aktivitas yang baik. Rasulullah shallallahu 'alaihi wa sallam bersabda: "Orang yang mencari nafkah bagi jandanya Dan orang miskin seperti orang yang berperang di jalan Allah, atau orang yang berdiri di malam hari, yang berpuasa di siang hari."

Dalam pengertian komprehensif ini, ibadah menjadi penghubung permanen antara Muslim dan Tuhannya. Jika kekomprehensifan dan keterpaduan merupakan salah satu ciri ketuhanan, maka hal tersebut termasuk dalam ciri kurikulum pendidikan Islam, yaitu aspek terapan dari prinsip-prinsip pendidikan. Jadi, itu bukan tujuan itu sendiri, tetapi sarana untuk mencapai tujuan, yang merupakan pengembangan komprehensif dari kepribadian pribadi manusia: tubuhnya, pikirannya, dan hati nuraninya. Ini mensyaratkan bahwa kurikulum yang disiapkan untuk tujuan ini harus komprehensif dan terintegrasi dalam pengalamannya dan semua aspek kegiatannya.

Integrasi aspek pengalaman manusia ke dalam kurikulum pendidikan Islam sejalan dengan gagasan Islam tentang alam semesta, keberadaan, dan manusia. Semua keberadaan berasal dari kehendak langsung Tuhan. Integrasi aspek pengalaman manusia dalam kurikulum pendidikan Islam sejalan dengan konsepsi Islam tentang kesatuan keberadaan dan integrasi bagian-bagiannya, karena ia memancar dari kehendak langsung Yang Maha Esa yaitu Allah. Integrasi aspek kepribadian manusia dalam konsep pendidikan Islam sejalan dengan konsepsi Islam tentang 
kesatuan individu manusia, dan kesatuan seluruh umat manusia. Manusia individu adalah satu kesatuan yang terpadu, dan berbagai kekuatannya disatukan dalam arah. Ia bukanlah tubuh yang independen dari jiwa dan pikiran. Itu bukan pikiran yang terpisah yang tidak ada hubungannya dengan tubuh dan jiwa, dan itu bukan jiwa yang mengembara tanpa tautan dari pikiran.

Dengan demikian, kesatuan kepribadian manusia, dan kesatuan integrasi pengalaman manusia dalam kurikulum pendidikan Islam sesuai dengan Islam, yaitu agama tauhid, dan agama persatuan dan kesatuan antar kekuatan.

2) Karakteristik Kelima : Keseimbangan

Keseimbangan merupakan ciri keenam kurikulum Islam. Keseimbangan antara sumber-sumber pengetahuan, antara menerima dari wahyu dan teks, dan menerima dari alam semesta dan kehidupan. Islam tidak menjadi radikal seperti halnya kepercayaan, doktrin dan filosofi lainnya, tidak seperti yang terjadi di eropa untuk mengambil "wahyu", sendirian sebagai sumber pengetahuan, kemudian berpaling dari wahyu ke "akal", dan mengambilnya sendiri sebagai sumber ilmu, kemudian berpaling dari akal dan mengambil "alam", semata sebagai sumber ilmu yang tidak "sembarangan". Pengabaian, tetapi mengambil Islam dari semua sumber, dan seimbang di antara mereka, dan memberikan masing-masing dari mereka apa yang layak derajat dan pertimbangan, Berikut ini adalah beberapa bentuk dari ciri keenam kurikulum Islam yaitu:

a) Ada keseimbangan antara apa yang dirasakan dan diterima seseorang, dan pekerjaannya berakhir dengan penyerahan diri, dan apa yang diterima, dirasakan, dicari alasannya, bukti, dan tujuannya, memikirkan persyaratan praktisnya, dan menerapkannya dalam kehidupannya yang sebenarnya. Manusia tidak dapat memahami segala sesuatu yang ada, karena kesadarannya tidak mencakup segalanya. Jadi Tuhan memberikan kenyamanan dalam sifatnya untuk yang tidak diketahui dan yang diketahui, dan keseimbangan menunjukkan ini dan itu dalam keberadaannya. b) Keseimbangan antara kemurnian kehendak ilahi dan stabilitas normanorma universal. Kehendak ilahi itu bebas, ia melakukan segalanya dan apa pun kapan pun ia mau, dan ia tidak terikat oleh aturan atau hukum, jadi ketika ia menginginkan ia melakukan apa yang ia inginkan.

c) Keseimbangan antara domain kehendak bebas ilahi dan domain kehendak manusia yang terbatas, yaitu isu yang dikenal dengan isu "Takdir dan Takdir" atau Aljabar dan pilihan.

d) Keseimbangan antara pengabdian mutlak manusia kepada Tuhan, dan kedudukan terhormat manusia di alam semesta. Islam telah terhindar dari ekstremisme di mana sekte-sekte dan filsafat telah jatuh, antara memuliakan manusia ke titik pendewaan sekali, dan meremehkan dia ke titik penghinaan dan penghinaan lagi. Islam membuat pemisahan kategoris antara realitas ketuhanan, stasiun dan karakteristiknya, dan realitas perbudakan dan stasiunnya.

e) Keseimbangan antara sumber-sumber ilmu, antara penerimaan dari wahyu dan teks, dan penerimaan dari alam semesta dan kehidupan. Islam tidak bertindak ekstrem seperti yang dilakukan oleh akidah, doktrin, dan falsafah lainnya, tidak seperti yang terjadi di Eropa dengan mengambil "wahyu" saja sebagai sumber pengetahuan, kemudian berpaling dari wahyu ke "akal" dan menjadikannya sebagai sumber pengetahuan. sumber pengetahuan, kemudian berpaling dari akal dan mengambil "alam" saja sebagai sumber pengetahuan. Islam tidak sewenang-wenang dan tidak menjadi ekstrimis hingga "mendewakan" sumber yang diterimanya sementara sama sekali mengabaikan sumber lainnya. Berdasarkan pada kenyataan bahwa alam semesta dan manusia dan semua kehidupan dan makhluk hidup diciptakan oleh Tuhan saja, maka sumber pengetahuan manusia adalah Wahyu, Alam semesta dan semua kehidupan dan makhluk hidup, dan Manusia itu sendiri adalah salah satu sumber perenungan dan pengetahuan melalui pikiran, dan teksteks Al-Qur'an. 
Dengan demikian, sumber-sumber ilmu dalam Islam seimbang, dan masing-masing dikoordinasikan sesuai dengan bobotnya, tanpa melebih-lebihkan.

3) Karakteristik Kelima : Positif

Karakteristik ketujuh dari sistem atau metode Islam umum adalah kepositifan, dan kepositifan memiliki dua bentuk seperti yang dikatakan Profesor Sayed Qutb yaitu Kepositifan aktif dalam hubungan Tuhan Maha Suci Dia dengan alam semesta, kehidupan dan manusia, dan kepositifan aktif dari sudut pandang manusia itu sendiri, dalam batas-batas bidangnya kemanusiaan.

Dalam konsepsi Islam, tidak ada keraguan tentang kepositifan Tuhan Yang Maha Esa dalam hubungannya dengan semua makhluknya, termasuk manusia. Dalam konsepsi Islam, manusia berurusan dengan Tuhan yang ada, Pencipta, Direktur, Yang Berkuasa, Yang Mampu, dan Aktif untuk apa yang dia inginkan penuh dengan kepositifan dan efektivitas milik-Nya semua masalah. Dan atas kehendak-Nya penciptaan alam semesta ini kembali ke awal, dan setiap kemunculan kembali setelah itu, dan setiap gerakan, dan setiap perubahan, dan setiap perkembangan, dan tidak ada yang selesai di alam semesta ini kecuali dengan kehendak, pengetahuan, penghargaan dan takaranNya. Al-Qur'an penuh dengan menyatakan kebenaran dasar ini, yaitu kepositifan Tuhan - Maha Suci Dia - dalam hubungannya dengan alam semesta, kehidupan dan makhluk hidup, termasuk manusia "Dan Tuhanmu adalah Tuhan yang menciptakan langit dan bumi dalam enam hari, kemudian bersemayam di atas 'Arsy, malam menutupi siang, siang mencarinya, dan matahari, bulan, dan bintang-bintang tunduk kepada-Nya. perintah. Kecuali Dia milik ciptaan dan perintah. Maha Suci Allah, Tuhan semesta alam" (Al-A'raf : 45).

\section{SIMPULAN DAN SARAN}

\section{A. Simpulan}

Berdasarkan kajian yang telah dilakukan terkait kurikulum islam menurut Ali Ahmad Madkur diatas, maka dapat di peroleh sepuluh pokok pikiran Ahmad Ali Madkur, yaitu: 1) Sesungguhnya integrasi pengalaman manusia didalam kurikulum pendidikan Islam relevan dengan pemikiran Islam alam (al-kaun), penciptaan dan manusia, 2) Sesungguhnya aturan-aturan langit seharusnya menciptakan kesatuan prinsip, yaitu; seluruhnya dari Allah yang satu dan mengajak/menyeru kepada prinsip-prinsip aqidah yakni beriman kepada Allah yang satu (Yang Maha Esa), 3) Asal penciptaan itu adalah satu, dan penciptaan itu merupakan sumber kehendak langsung dari Allah Yang Maha Esa, 4) Asal agama-agama itu adalah satu, yaitu beribadah kepada Allah dan tidak menyekutukan-Nya, 5) Para Nabi asalnya adalah satu, dan mereka merupakan umat yang satu serta memiliki tujuan yang satu pula, 6) Asal alam itu adalah terintegrasi, asal humaniora yang satu itu juga adalah terintegrasi, 7) Sesungguhnya tujuan pengetahuan dan belajar dalam kurikulum pendidikan Islam adalah pembentukan manusia yang mampu secara positif dan aktif (interaktif) didalam membangun atau mengolah bumi (sumber Daya Alam) sesuai dengan metode (pedoman, aturan) Allah SWT, 8) Integrasi itu ada tiga macam, yaitu; integrasi horizontal, vertical dan eksternal, 9) Sesungguhnya integrasi itu tujuan akhirnya adalah komunikasi belajar untuk mencapai hasil paripurna (darajat-u al-kamal) yang telah disiapkan (difasilitasi) oleh Allah SWT, 10) Sesungguhnya materi kurikulum itu, memungkinkan untuk dibagi menjadi enam bidang yang saling melengkapi, diantaranya; ilmu-ilmu puisi dan hukum, ilmu-ilmu humaniora, ilmu-ilmu eksakta, ilmu-ilmu biologi, ilmu-ilmu seni ekspresif dan pendidikan olah raga.

\section{B. Saran}

Penelitian ini merupakan kajian awal tentang kurikulum islam menurut Ali Ahmad Madkur, sehingga diperlukan adanya tindak lanjut yang lebih mendalam dalam membahas landasan teori dan praktik dalam kurikulum Islam. Pada penelitian berikutnya bisa menggunakan penelitian studi kepustakaan mengenai landasan teori dan praktik kurikulum Islan dengan membuat penelitian pengembangan ataupun penerapan dengan rujukan pustaka mengenai landasan teori dan praktik kurikulum Islam dalam menghadapi era revolsi indstri 4.0.

\section{DAFTAR RUJUKAN}

Al-Abrasy. (1985). Dasar-dasar Pokok Pendidikan Islam. (Jakarta: Bulan Bintang. 
Al-Syaibani. (1979). Falsafah At-Tarbiyah AlIslamiyah. Jakarta:Bulan Bintang.

Arifudin, 0. (2021). Konsep Dasar Pendidikan Anak Usia Dini. Bandung: Widina Bhakti Persada Bandung.

Bahri, A. S. (2021). Pengantar Penelitian Pendidikan (Sebuah Tinjauan Teori dan Praktis). Bandung: Widina Bhakti Persada.

Hasbi, I. (2021). Administrasi Pendidikan (Tinjauan Teori Dan Praktik). Bandung: Widina Bhakti Persada.

Irwansyah, R. (2021). Perkembangan Peserta Didik. Bandung: Widina Bhakti Persada.

Juhji. (2020). Manajemen Humas Sekolah. Bandung: Widina Bhakti Persada.

Mayasari, A. (2021). Implementasi Sistem Informasi Manajemen Akademik Berbasis Teknologi Informasi dalam Meningkatkan Mutu Pelayanan Pembelajaran di SMK. JIIPJurnal Ilmiah Ilmu Pendidikan, 4(5), 340345.

https://doi.org/https://doi.org/10.54371/j iip.v4i5.277

Nadeak, B. (2020). Manajemen Humas Pada Lembaga Pendidikan. Bandung: Widina Bhakti Persada.
Rahayu, Y. N. (2020). Program Linier (Teori Dan Aplikasi). Bandung : Widina Bhakti Persada.

Sofyan, Y. (2020). Peranan Konseling Dosen Wali Dalam Meningkatkan Motivasi Belajar Mahasiswa Di Perguruan Tinggi Swasta Wilayah LLDIKTI IV. Jurnal Bimbingan Dan Konseling Islam, 10(2), 237-242.

Sugiyono. (2015). Metode Penelitian Pendidikan (Pendekatan Kuantitatif. Kualitatif dan $R \& D)$. Bandung : CV. Alfabeta.

Tanjung, R. (2019). Manajemen Pelayanan Prima Dalam Meningkatkan Kepuasan Mahasiswa Terhadap Layanan Pembelajaran (Studi Kasus di STIT Rakeyan Santang Karawang). Jurnal Ilmiah MEA (Manajemen, Ekonomi, \& Akuntansi), 3(1), 234-242.

Tanjung, R. (2021). Kompetensi Manajerial Kepala Sekolah Dalam Meningkatkan Kinerja Guru Sekolah Dasar. JIIP-Jurnal Ilmiah Ilmu Pendidikan, 4(4), 291-296. https://doi.org/https://doi.org/10.54371/i iip.v4i4.272 